\title{
FIRST RECORD OF Anopheles (Anopheles) costai FONSECA \& RAMOS, 1939 IN ESPÍRITO SANTO STATE, BRAZIL
}

Delsio NATAL(1), Paulo Roberto URBINATTI(1), Rosely dos Santos MALAFRONTE(2,3), Helder Ricas REZENDE(4), Crispim CERUTTI Jr.(3,5)

\& Maria Anice Mureb SALLUM(1)

\begin{abstract}
SUMMARY
Field collections of immatures and adults of Culicidae were carried out in the Rio Doce Valley, Espírito Santo State, aiming to increase knowledge on the anopheline species of that region. Considering all Culicidae species collected, among other anopheline it is noteworthy the presence of Anopheles darlingi, An. oswaldoi and An. costai. Regarding to An. darlingi, responsible for malaria outbreak in the low lands in that state, it was expected to confirm its presence in the area. The register of specimens of $A n$. costai in the field collections is relevant, increasing the geographical distribution of the species and representing better knowledge of the Series Arribalzagia of the subgenus Anopheles.
\end{abstract}

KEYWORDS: Anopheles costai; Distribution; First register; Espírito Santo; Brazil.

\section{INTRODUCTION}

Human malaria remains one of the major public health problems in Brazil. In the Amazon area, where 95\% of all Latin America malaria cases are reported, the primary vector is An. darlingi Root, an endophilic and anthropophilic species highly susceptible to infection with Plasmodium parasites ${ }^{8,9}$. In localities situated outside the Amazon region, every year cases of malaria originated either from areas situated in the Amazon or other countries, i.e. African and Latin American countries are notified. However, in the dynamics of malaria transmission within the southern Atlantic Forest ecosystem, where Anopheles (Kerteszia) mosquitoes are frequent, malaria transmission is associated with two species, i.e. An. cruzii and An. bellator, both considered primary vectors.

Out of more than 500 species of Anopheles in the world approximately 100 occur in the Neotropical Region ${ }^{12}$. Of those found in Latin America, 29 have been indicated as potential human malaria vectors ${ }^{10}$. While in the Amazon area the primary vector is An. darlingi $i^{5,16}$ in Mexico and Central America An. (Anopheles) pseudopunctipennis and An. albimanus $^{14}$ are major vectors. However, these are not the only malaria vectors and research based on radioimmunoassay (RIA) and enzyme-linked immunosorbent assay (ELISA) has identified other anopheline species playing potentially important roles in malaria transmission in Latin America ${ }^{1-4,8,9,11,16,18}$.

In the published literature data, there are fifteen Nyssorhynchus species that have been registered as potential vectors of human
Plasmodium $^{10}$. However, these data should be analyzed with caution because the literature may include false-positive data for mosquitoes that have just or recently fed on human blood infected with malaria parasites, mainly because infections have been detected by direct microscopic observation, immunological and molecular approaches. Epidemiological studies designed to incriminate malaria vector species are rare or incomplete. In Brazil, where several species of the genus Anopheles are registered, it is plausible to hypothesize that in any area, where both a competent vector species in high density and infected humans are present, it will be possible to have active Plasmodium transmission and consequently, autochthonous cases of malaria.

The subgenera Nyssorhynchus and Kerteszia include several species that have been demonstrated to be competent to transmit Plasmodium. Consequently, species of these two subgenera have been studied in several biological aspects, including taxonomy, systematic, ecology and control. The subgenus Anopheles contains several species that occur in Brazil, however it is poorly known and species identification is usually problematic. Consequently, a proper knowledge of the genus Anopheles in ecological and systematic aspects, including phylogenetic relationships among the species is relevant. Within these circumstances, to design an effective malaria control program, it is fundamental to know potential vector species that occur in the area where the program will be implemented.

It is well known that a fundamental step towards the recognition of the target species is the accurate identification of field captured specimens. As a natural consequence of epidemiological studies on

(1) Faculdade de Saúde Pública da Universidade de São Paulo, Departamento de Epidemiologia, São Paulo, SP, Brasil.

(2) Instituto de Medicina Tropical de São Paulo, Laboratório de Protozoologia, São Paulo, SP, Brasil.

(3) Faculdade de Medicina da Universidade de São Paulo, Departamento de Doenças Infecciosas e Parasitárias, São Paulo, SP, Brasil.

(4) Secretaria de Estado da Saúde, Governo do Estado do Espírito Santo, Espírito Santo, ES, Brasil.

(5) Universidade Federal do Espírito Santo, Centro Biomédico, Departamento de Medicina Social, Vitória, ES, Brasil.

Correspondence to: Delsio Natal, Av. Dr. Arnaldo 715, 01246-904 São Paulo, SP, Brasil. E-mail: natal@usp.br 
malaria conducted in the hilly area of the Espirito Santo State, where An. cruzii of the subgenus Kerteszia has been registered and autochthones cases of malaria ${ }^{13}$, field collection of immatures have been carried out aiming to obtain mosquito samples with all stages associated. Collection of immatures were carried out in both hilly areas and in low lands in the Rio Doce Valley. As a result, we are reporting for the first time the occurrence of An. costai in Espirito Santo State. This report enlarge the geographical distribution range of the taxon and contributes for a better knowledge of the subgenus Anopheles in Brazil.

\section{MATERIALS AND METHODS}

Immatures and adults of Culicidae were collected in January 2006 in localities situated in the Rio Doce Valley, Espírito Santo State, in the following municipalities and respective localities: i) Linhares, Lagoa Juparanã (19 $\left.18.311^{\prime} \mathrm{S}, 40^{\circ} 05.84^{\prime} \mathrm{W}\right)$ and Chapadão do XV (19 20.917' S 40 07.103' W); ii) Sooretama (19² 02.674' S 40 03.098' W), Joerama-A, Córrego Cupido (19 ${ }^{\circ} 02.753^{\prime}$ S $40^{\circ} 00.682^{\prime} \mathrm{W}$ ) and Pequi Farm (19 04.984' S $40^{\circ} 06.880^{\prime}$ W); iii) Jaguaré, Barra Seca ( $18^{\circ} 59.693^{\prime}$ S $40^{\circ} 00.129^{\prime} \mathrm{W}$ ) and Lagoa do Macuco, Marianelli Farm (1902.089' S 39 56.909' W).

Immatures were taken from breeding habitats such as ground ponds and swamps by using regular entomological collecting pans. Fourthinstar larvae were individually separated in small plastic vials using the same water of the breeding habitats. Larvae were kept separate until the emergence of the correspondent pupae and adults. After the emergence of the adults, they were kept alive for 24 hours before being killed with ethyl acetate. Species identifications were based on all stages, including male genitalia.

Adults were captured using Shannon trap. Adult collections were carried out in the extra domiciliary environment, in both open areas and inside remaining forest located nearby the edges of the Sooretama Forest Reserve. Adults were kept alive in small glass vials, where they were blood fed. They were transported to the laboratory inside boxes and kept alive for about 48 hours, when they were induced to oviposition by cutting one of the wings.

\section{RESULTS}

Culicidae species which were collected during the field work carried out in areas of the Rio Doce Valley are listed in Table 1. It is worth to note the presence of An. darlingi, the major vector of Plasmodium in Brazil. Samples of this species were captured in both a community farm area designated Assentamento Joerama A and in the Pequi Farm, both in Sooretama municipality. Additionally, topotypes of An. oswaldoi were collected inside a forest fragment situated in Marianelli Farm situated in the area of Lagoa do Macuco, in Jaguaré municipality. The Rio Doce Valley area represents the type-locality of An. oswaldoi. Two adult females of An. oswaldoi were captured in Shannon trap using both human and light attraction. Among the anopheline specimens collected in Lagoa do Macuco, Jaguaré and in Joerama A, Sooretama municipality, a few samples of An. (Anopheles) costai were found. Figure 1 shows the major morphological characters employed in the recognition of An. costai.

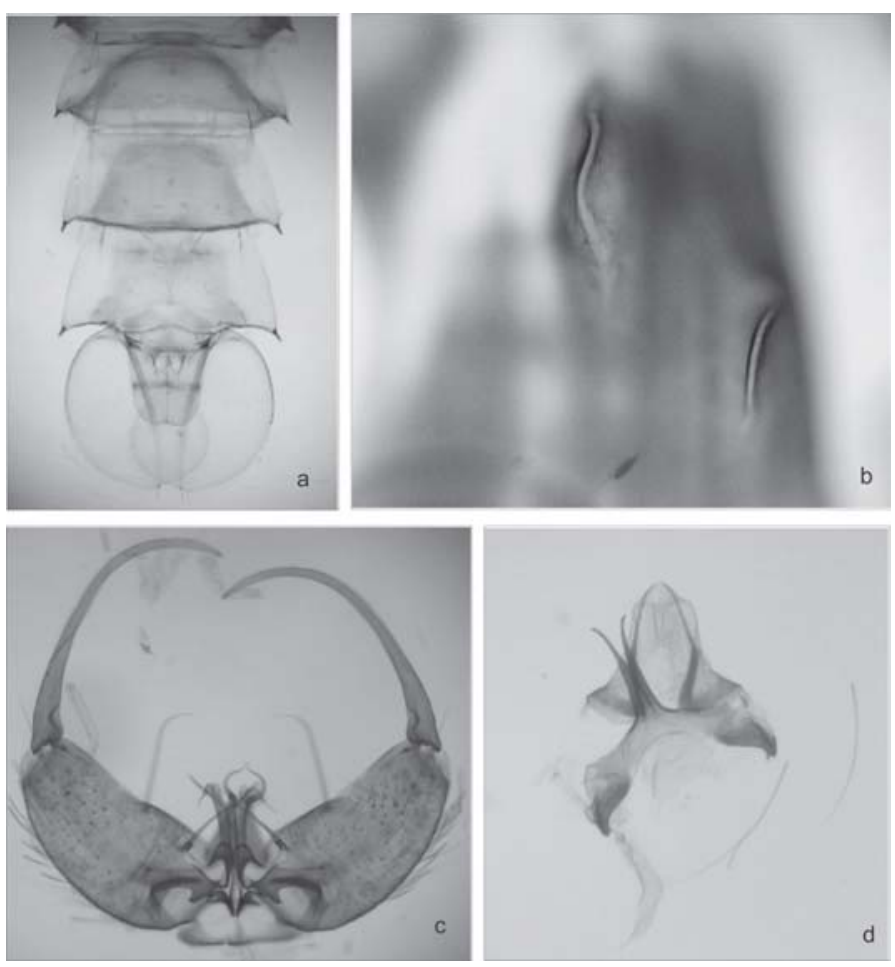

Fig. 1 - Morphological characters that are important for identification of Anopheles costai. The microphotos were taken from an adult male specimen collected in Marianelli Farm, Jaguaré municipality, Espírito Santo State, Brazil. a: Terminal segments (apex of V-IX, paddle) of the abdomen of a male specimen; b: Wing case of a pupa, showing two protuberances; $c$ : Male genitalia, general aspect; d: Ninth tergal lobe of the male genitalia and proctiger.

Table 1

Presence of species of the genus Anopheles collected and their respective collection localities in Espírito Santo State, Brazil, in January 2006

\begin{tabular}{lccccc}
\hline & \multicolumn{3}{c}{ Localities } \\
\cline { 2 - 6 } Species & Lagoa do Macuco & Joerama A & Lagoa Juparanã & Chapadão do XV & Fazenda Pequi \\
\hline An. oswaldoi & $\mathrm{X}$ & $\mathrm{X}$ & $\mathrm{X}$ & $\mathrm{X}$ \\
An. triannulatus & $\mathrm{X}$ & $\mathrm{X}$ & $\mathrm{X}$ & $\mathrm{X}$ \\
An. albitarsis s.1. & $\mathrm{X}$ & $\mathrm{X}$ & $\mathrm{X}$ & $\mathrm{X}$ \\
An. minor & $\mathrm{X}$ & $\mathrm{X}$ & $\mathrm{X}$ & $\mathrm{X}$ \\
An. darlingi & & $\mathrm{X}$ & & \\
An. kompilcarorii & $\mathrm{X}$ & $\mathrm{X}$ & & \\
An. costai & & & & \\
\hline
\end{tabular}




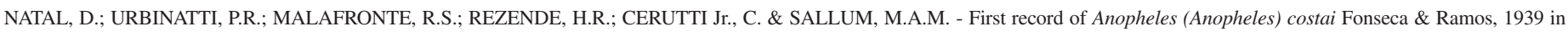
Espírito Santo State, Brazil. Rev. Inst. Med. trop. S. Paulo, 49(5): 323-326, 2007.

In addition to the Anophelinae species listed in Table 1, the following Culicidae were collected: Aedeomyia (Aedeomyia) squamipennis; Culex (Aedinus) accelerans; Culex (Culex) coronator; Culex (Melanoconion) ensiformis; Culex (Melanoconion) idottus; Culex (Melanoconion) spp.; Uranotaenia (Uranotaenia) geometrica and Uranotaenia (Uranotaenia) natalie.

All the specimens obtained in the field collections were deposited in Reference Collections of Faculdade de Saúde Pública da Universidade de São Paulo.

\section{DISCUSSION}

According to data collected by the Vigilância Ambiental do Sistema Único de Saúde, during the period from 1985 until 2006 4,870 autochthonous and imported cases of malaria were registered in Espírito Santo State. The majority of cases were reported in municipalities situated in the hilly area of that state, where An. cruzii of the subgenus Kerteszia is a potential vector ${ }^{13}$ and in the low lands, where species of the subgenus Nyssorhynchus and Anopheles are more prominent than Kerteszia species. Presence of An. darlingi in the Rio Doce Valley was expected, because the local vector control personnel had already registered the species and attributed its presence to malaria epidemics in low land areas.

Regarding to specimens of An. oswaldoi collected in Marianelli Farm, they represent topotypes specimens that were obtained from eggs oviposited by field collected females. These specimens of $A n$. oswaldoi are deposited in the Entomological collection of Faculdade de Saúde Pública/USP (FSP-USP). These topotypes will be important for studies that objective both morphological and molecular characterization of the species.

Additionally, An. costai is morphologically similar to other species of the Series Arribalzagia, especially An. forattinii $^{17}$ and An. mediopunctatus ${ }^{15}$. These three species were misidentified as $A n$. mediopunctatus for several years, as a consequence of identifications based only on adult female characters. However, field collected specimens associated with immatures and adult females and males carried out in the Ribeira Valley, southern of Atlantic Forest and in Brazilian Amazon areas made possible to achieve an accurate separation of the three species. Anopheles costai was in the synonymy of An. mediopunctatus for several years. It was described by FONSECA \& RAMOS, in $1939^{6}$ based on specimens collected in São Vicente municipality, São Paulo State. Recently, SALLUM et al..$^{15}$ resurrected An. costai from synonymy. The geographical distribution range of An. costai is poorly known in Brazil. The taxon has been registered in localities of São Paulo, Rondônia, Bahia, Minas Gerais and Pará States, as well as in other South American countries $^{15}$. The first report of An. costai in the Rio Doce Valley increases the distribution range of the taxon in Atlantic Forest and suggest that specimens identified as An. mediopunctatus in that state may include samples of An. costai that have been misidentified as An. mediopunctatus. Consequently, one should be cautious when identifying specimens as An. mediopunctatus because similarly to what occur in the Ribeira Valley, São Paulo, An. costai and An. mediopunctatus may be sympatric in the Rio Doce Valley. This hypothesis should be tested with additional field collections in the Rio Doce Valley and other poorly sampled areas of Espírito Santo State.
Epidemiological importance of An. costai is poorly known, however there are evidences that show a possible involvement of the species in the dynamics of malaria transmission in some areas in Brazil. TADEI \& DUTARY-THATCHER ${ }^{16}$ hypothesized that An. mediopunctatus may be participating of malaria transmission in areas of the Amazon Region. Considering that An. mediopunctatus seems to occur only in areas of the Atlantic Forest, southern Brazil, it is possible to hypothesize that the specimens identified by TADEI \& DUTARY-THATCHER ${ }^{16}$ may be of either An. costai or An. forattinii, which occur in Amazon areas. Furthermore, KLEIN et al. ${ }^{8,9}$ showed that specimens of An. costai that were misidentified as An. mediopunctatus, are susceptible to be infected by Plasmodium falciparum and P. vivax.

In conclusion, although morphological characters are available to identify most of the Anopheles species, distinction of closely-related species is problematic, and additional differential traits should be employed, for example those of male genitalia and external morphology of the eggs. Additionally, while research in malaria vectors is based on data provided by single or few field captured mosquitoes, the design of adequate control measures will not be achieved. Consequently, ways to achieve an accurate species identification should be considered by researchers working with Latin American anophelines in order to produce reliable and high-quality results that will provide basis for effective surveillance and control strategies in the countries where malaria occurs.

\section{RESUMO}

\section{Sobre o encontro de Anopheles (Anopheles) costai Fonseca \& Ramos, 1939 no Estado do Espírito Santo, Brasil}

Empreenderam-se coletas de imaturos e adultos de Culicidae no Vale do Rio Doce, Estado do Espírito Santo, Brasil, com o objetivo de ampliar o conhecimento sobre os anofelíneos dessa região. Do material obtido, além de outros anofelíneos e demais mosquitos, destaca-se a presença de Anopheles darlingi, An. oswaldoi e An. costai. Quanto ao An. darlingi, responsável por surtos de malária nas regiões baixas daquele Estado, já se esperava a confirmação de sua presença. Assinalase como relevante a captura de espécimes de An. costai, ampliando-se a distribuição geográfica da espécie, bem como, trazendo contribuição para o conhecimento da Serie Arribalzagia do subgênero Anopheles.

\section{ACKNOWLEDGEMENTS}

We thanks Fundação de Amparo à Pesquisa do Estado de São Paulo for financial support (FAPESP Grants 05/53973-0 and 03/07631-4); A. B. de Oliveira for his help in the field collections.

\section{REFERENCES}

1. ARRUDA, M.; CARVALHO, M.B.; NUSSENZWEIG, R.S. et al. - Potential vectors of malaria and their different susceptibility to Plasmodium falciparum and Plasmodium vivax in northern Brazil identified by immunoassay. Amer. J. trop. Med. Hyg., 35: 873-881, 1986.

2. BRANQUINHO, M.S.; ARAÚJO, M.S.; NATAL, D. et al. - Anopheles oswaldoi a potential malaria vector in Acre, Brazil. Trans. roy. Soc. trop. Med. Hyg., 90: 233, 1996.

3. BRANQUINHO, M.S.; TAIPE-LAGOS, C.B.; ROCHA, R.M. et al. - Anophelines in the State of Acre, Brazil, infected with Plasmodium falciparum, $P$. vivax, the variant $P$. vivax VK247 and P. malariae. Trans. roy. Soc. trop. Med. Hyg., 87: 391-394, 1993. 


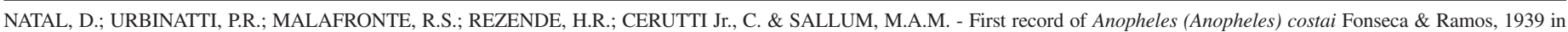
Espírito Santo State, Brazil. Rev. Inst. Med. trop. S. Paulo, 49(5): 323-326, 2007.

4. CALDERÓN, G.; FERNÁNDEZ, R. \& VALLE, J. - Especies de la fauna anofelina, su distribución y algunas consideraciones sobre su abundancia e infectividad en Perú. Rev. peru. Epidem., 8: 5-23, 1995.

5. DEANE, L.M. - Malaria vectors in Brazil. Mem. Inst. Oswaldo Cruz, 81 (suppl. 2): 5$14,1986$.

6. FONSECA, F. \& RAMOS, A.S. - Novo subgênero e novas espécies de anofelinas neotropicas (Diptera. Culicidae). Mem. Inst. Butantan, 13: 383-392, 1939.

7. GUIMARÃES, J.H. - Systematic database of Diptera of the Americas South of the United States (family Culicidae). São Paulo, Plêiade; Fapesp, 1997.

8. KLEIN, T.A.; LIMA, J.B. \& TADA, M.S. - Comparative susceptibility of anopheline mosquitoes to Plasmodium falciparum in Rondonia, Brazil. Amer. J. trop. Med. Hyg., 44: 598-603, 1991.

9. KLEIN, T.A.; LIMA, J.B.P.; TADA, M.S \& MILLER, R. - Comparative susceptibility of anopheline mosquitoes in Rondônia, Brazil, to infection by Plasmodium vivax. Amer. J. trop. Med. Hyg., 45: 463-470, 1991.

10. MARRELLI, M.T.; SALLUM, M.A.M. \& MARINOTTI, O. - The second internal transcribed spacer of nuclear ribosomal DNA as a tool for Latin American anopheline taxonomy - a critical review. Mem. Inst. Oswaldo Cruz, 101: 817-832, 2006.

11. MARRELLI, M.T.; BRANQUINHO, M.S.; HOFFMANN, E.H. et al. - Correlation between positive serology for Plasmodium vivax-like/Plasmodium simiovale malaria parasites in the human and anopheline populations in the State of Acre, Brazil. Trans. roy. Soc. trop. Med. Hyg., 92: 149-151, 1998.
12. PAPAVERO, N. \& GUIMARÃES, J.H. - The taxonomy of Brazilian insects vectors of transmissible diseases (1900-2000) - then and now. Mem. Inst. Oswaldo Cruz, 95: 109-118, 2000

13. REZENDE, H.R.; CERUTTI-Jr., C. \& SANTOS, C.B. - Aspectos atuais da distribuição geográfica de Anopheles (Kerteszia) cruzii Dyar \& Knab, 1908 no Estado do Espírito Santo, Brasil. Entomol. Vect., 12: 123-126, 2005.

14. RODRIGUEZ, M.H. - Malaria and dengue vector biology and control in Latin America. In: KNOLS, B.G.J. \& LOUIS, C. Bridging laboratory and field research for genetic control of disease vectors. Dordrecht, Wageningen UR Frontis Series; Springer, 2006. p. 129-144.

15. SALLUM, M.A.; WILKERSON, R.C. \& FORATTINI, O.P. - Taxonomic study of species formely identified as Anopheles mediopunctatus and resurrection of An. costai (Diptera: Culicidae). J. med. Entomol., 36: 282-300, 1999.

16. TADEI, W.P. \& DUTARY-THATCHER, B. - Malaria vectors in the Brazilian Amazon: Anopheles of the subgenus Nyssorhynchus. Rev. Inst. Med. trop. S. Paulo, 42: 8794, 2000.

17. WILKERSON, R.C. \& SALLUM, M.A.M. - Anopheles (Anopheles) forattinii: a new species in Series Arribalzagia (Diptera: Culicidae). J. med. Entomol., 36: 345-354, 1999.

18. ZIMMERMAN, R.H. - Ecology of malaria vectors in the Americas and future direction. Mem. Inst. Oswaldo Cruz, 87 (suppl. 3): 371-383, 1992.

Received: 8 January 2007

Accepted: 23 May 2007 